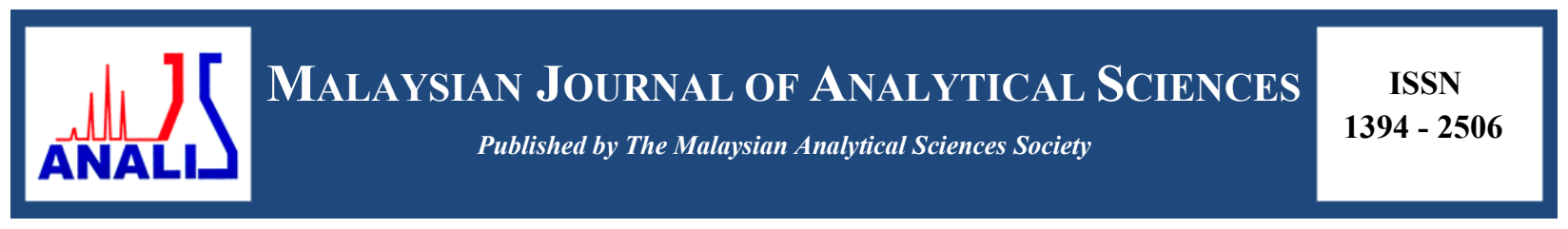

\title{
SYNTHESIS, CRYSTAL STRUCTURE AND COORDINATION CHEMISTRY OF DI-2-PYRIDYLMETHANEAMINE-BASED CHELATING LIGANDS WITH CADMIUM SALTS
}

\author{
(Sintesis, Struktur Hablur dan Kimia Koordinatan Ligan Pengkelat Berasaskan \\ Di-2-Piridilmetanaamina dengan Garam Kadmium) \\ Maisara Abdul Kadir ${ }^{1 *}$ and Christopher James Sumby ${ }^{2}$ \\ ${ }^{1}$ School of Fundamental Science, \\ Universiti Malaysia Terengganu, 21030 Kuala Nerus, Terengganu, Malaysia \\ ${ }^{2}$ School of Physical Sciences, Centre for Advanced Nanomaterials, \\ The University of Adelaide, Adelaide, South Australia 5005, Australia \\ *Corresponding author: maisara@umt.edu.my
}

Received: 16 August 2016; Accepted: 17 July 2017

\begin{abstract}
Chelating ligands play a prominent role as organic linker in the construction of multinuclear complexes due to their strong binding to metal ions. Thus, in this study, two new bridging ligands with chelating arms, namely $1,3-N, N^{\prime}-[$ bis (di(pyridin-2yl)methyl)]isophthalamide (L1) and 1,4-N,N'-bis[(di(pyridin-2-yl)methyl)]terephthalamide (L2) were successfully synthesized and characterized using Fourier Transform Infrared (FTIR), ${ }^{1} \mathrm{H}$ and ${ }^{13} \mathrm{C}$ Nuclear Magnetic Resonances $\left({ }^{1} \mathrm{H}\right.$ and ${ }^{13} \mathrm{C}$ NMR) and Xray crystallography. Reaction of $\mathrm{L} 1$ and $\mathrm{L} 2$ with metal salts gave two multinuclear cadmium complexes, with formula molecules $\left[\left\{\mathrm{CdCl}_{2}\left(\mathrm{CH}_{3} \mathrm{OH}\right)(\mathrm{L} 1) \mathrm{CdCl}_{2}\right\}_{2}\right]$ and $\left[\left(\mathrm{CdBr}_{2}\right)_{2}\left(\mathrm{~L}_{2}\right)\left(\mathrm{CH}_{3} \mathrm{OH}\right)_{2}\right]$, respectively. X-ray crystallography reveals that ligands $\mathrm{L} 1$ and $\mathrm{L} 2$ used all four nitrogen donors from di-2-pyridylmethaneamine units to chelate with cadmium ions in forming stable multinuclear complexes. The complexes are also stabilized by supramolecular interactions such as hydrogen bonding and pi-pi stacking, as observed in the crystal packing.
\end{abstract}

Keywords: crystal, chelating ligands, synthesis, pi stacking, supramolecular

\section{Abstrak}

Ligan pengkelat memainkan peranan penting sebagai penghubung organik dalam pembentukan kompleks multinuklear kerana ikatan yang kuat terhadap ion logam. Oleh itu, dalam kajian ini, dua ligan penghubung baharu yang mempunyai kumpulan pengkelat, iaitu 1,3-N,N'-[bis(di(piyridin-2-il)metil)]isoptalamida (L1) dan 1,4-N,N'-bis[(di(piridin-2-il)metil)]tereptalamida (L2) telah berjaya disintesis dan dicirikan menggunakan analisis Inframerah Transformasi Fourier (FTIR), ${ }^{1} \mathrm{H}$ dan ${ }^{13} \mathrm{C}$ Resonan Magnetik Nuklear $\left({ }^{1} \mathrm{H}\right.$ dan ${ }^{13} \mathrm{C}$ RMN) dan kristalografi sinar-X. Kajian kimia koordinatan ligan L1 dan L2 dengan garam logam menghasilkan dua kompleks multinuklear kadmium dengan formula molekul masing-masing adalah $\left[\left\{\mathrm{CdCl}_{2}\left(\mathrm{CH}_{3} \mathrm{OH}\right)(\mathrm{L1}) \mathrm{CdCl}_{2}\right\}_{2}\right]$ dan $\left[\left(\mathrm{CdBr}_{2}\right)_{2}\left(\mathrm{~L}_{2}\right)\left(\mathrm{CH}_{3} \mathrm{OH}\right)_{2}\right]$. Kajian hablur kristalografi sinar-X menunjukkan bahawa ligan $\mathrm{L} 1$ dan L2 menggunakan empat atom penderma nitrogen dari di-2-piridilmetanaamina unit untuk berikatan pada ion kadmium dalam menghasilkan kompleks multinuklear yang lebih stabil. Kompleks ini turut distabilkan oleh interaksi supramolekul seperti ikatan hidrogen dan interaksi pertindihan pi-pi sebagaimana yang dilihat dalam padatan hablur.

Kata kunci: hablur, ligan pengkelat, sintesis, pertindihan pi, supramolekular 


\section{Introduction}

The use of bridging ligands that have the capacity to chelate each metal centre bridged by the ligand is important to improve the stability of multinuclear complexes or enhance metal-metal interactions [1-4]. Steel and co-workers for instance, have reported many complexes derived from the bridging ligands containing di-2-pyridyl chelating motifs such as di-2-pyridylamine (dpa) based bridging heterocyclic ligands with silver(I), copper(II) and palladium(II) [25]. On reaction with silver salts, the ligands act as divergent bridging unit, with only two of the four pyridine rings involved in the coordination to form 1-D coordination polymers. Conversely, on reaction with copper(II) and palladium(II), the ligand uses all four nitrogen donors to coordinate with the metal centres and form stable discrete dinuclear complexes [5]. Along with this interest, significant efforts have been paid to generate bridging ligands with flexible di-2-pyridyl chelating moieties [6-9]. The additional spacer at di-2-pyridyl chelating moieties is important not only to confer flexibility but also to minimise the potential for hydrolysis that plagues other related compounds described in the literature [2,4,5]. Also, by using flexible bridging ligands, a diverse range of complexes and crystal packing can be obtained.

Di-2-pyridylmethaneamine (dpma), is the example of flexible chelating ligand that consists of methylene spacer between di-2-pyridyl rings and amine. (Figure 1). Dpma compound has been studied by Trilla and co-workers in 2006 and has shown potential as recyclable catalyst in Suzuki cross coupling reactions [10]. Before that, it was synthesized and the coordination chemistry with ruthenium salts was investigated by Chang et al. [11]. However, it was a little surprise to discover that this chelating compound is less explored particularly as bridging ligands unit, and the reason behind this little attention was not mentioned in any reports. Therefore, in line with our interest to expand the repertoire of bridging ligands containing flexible pyridyl moieties available for studies [12-13] and to explore their coordination chemistry of the type of ligands, we have produced another two new doubly bidentate bridging ligands with dpma units appended to isophthalamide (L1) and terephthalamide (L2) core, as shown in Figure 1.<smiles>O=C(NC(c1ccccn1)c1ccccn1)c1cccc(C(=O)NC(c2ccccn2)c2ccccn2)c1</smiles>

L1

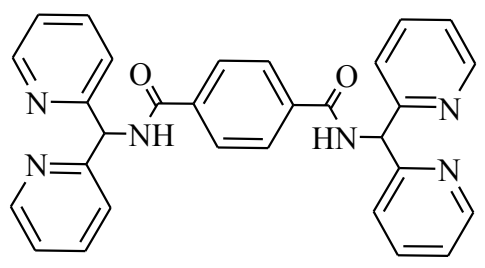

L2

Figure 1. The structure of two new doubly bidentate bridging ligands L1 and L2 described in this study

Basically, di-2-pyridylmethane chelating unit can coordinate to metal centres through three coordination modes, which are chelating, monodentate or bridging. Between the three modes, predominant coordination mode of the di2-pyridyl motif is to chelate to particular metal centre through the two nitrogen donor atoms (Figure 2). Therefore, this study is carried out to further investigate the chelating potential of the bridging ligands and identify the chelating modes preferred by compounds L1 and L2, respectively. 


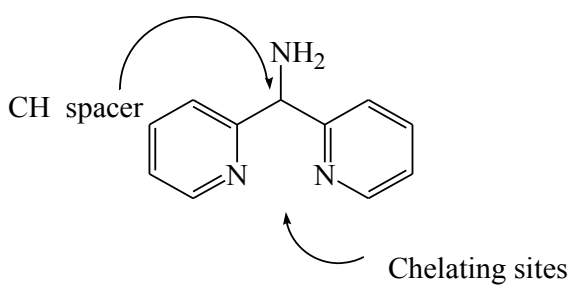

Figure 2. Molecular structure of di-2-pyridylmethaneamine (dpma) with $\mathrm{CH}$ spacer and metal ion chelating sites

\section{Instrumentations}

\section{Materials and Methods}

Elemental analyses were performed by the Campbell Microanalytical Laboratory at the University of Otago, Dunedin, New Zealand. Infrared spectra were collected on a Perkin Elmer Spectrum BX Infrared spectrometer as $\mathrm{KBr}$ disks. Nuclear Magnetic Resonances (NMR) spectra were recorded on Varian Gemini $300 \mathrm{MHz} \mathrm{NMR}$ spectrometer at $23{ }^{\circ} \mathrm{C}$ using a $5 \mathrm{~mm}$ probe. ${ }^{1} \mathrm{H}$ NMR spectra recorded in deuterated chloroform $\left(\mathrm{CDCl}_{3}-\mathrm{d}_{6}\right) ;{ }^{1} \mathrm{H}$ NMR spectra recorded in $\mathrm{CDCl}_{3}-\mathrm{d}_{6}$ which was referenced to the solvent peak: $7.24 \mathrm{ppm} .{ }^{13} \mathrm{C}$ NMR spectra were all referenced to their solvent peaks: $\mathrm{CDCl}_{3}, 77.23 \mathrm{ppm}$. Electrospray (ES) mass spectra were recorded using a Finnigan LCQ mass spectrometer by preparing serial dilutions of a $1 \mathrm{mg} / \mathrm{mL}$ solution of the compound. Crystals were analyzed by single crystal X-ray crystallography using Oxford Diffraction X-calibur at 150(2) K.

\section{Syntheses of the ligands: 1,3- $N, N^{\prime}$-[bis(di-(pyridin-2-yl)methyl)]isophthalamide (L1)}

Isophthaloyl chloride $(0.55 \mathrm{~g}, 2.8 \mathrm{mmol})$ was dissolved in dichloromethane $(40 \mathrm{~mL})$. Then, di- $(2-$ pyridyl)methylamine $(1.01 \mathrm{~g}, 5.5 \mathrm{mmol})$ and triethylamine $(0.76 \mathrm{~mL}, 5.5 \mathrm{mmol})$ were added to the solution and heated at reflux for 72 hours. The solvent was removed in vacuo to give a brown solid which was collected, washed with diethyl ether, dried and recrystallized from ethanol to give $\mathbf{L} 1$ as a light brown solid $(0.90 \mathrm{~g}, 63 \%)$.

\section{1,4-N, $N$ '-bis[(di(pyridin-2-yl)methyl)]terephthalamide(L2)}

Terephthaloyl chloride $(0.30 \mathrm{~g}, 1.5 \mathrm{mmol})$ was dissolved in dichloromethane $(40 \mathrm{~mL})$. Then, di-(2pyridyl)methylamine $(0.55 \mathrm{~g}, 3.0 \mathrm{mmol})$ and triethylamine $(0.41 \mathrm{~mL}, 3.0 \mathrm{mmol})$ were added to the solution and heated at reflux for 72 hours. The solvent was removed in vacuo to give a brown solid of $\mathbf{L 2}$. The solid was washed with diethyl ether, dried and recrystallized from ethanol to give $\mathbf{L} 2$ as a fine brown solid $(0.43 \mathrm{~g}, 57 \%)$.

\section{Syntheses of the cadmium complexes: $\left[\left\{\mathrm{CdCl}_{2}\left(\mathrm{CH}_{3} \mathrm{OH}\right)(\mathrm{L1}) \mathrm{CdCl}_{2}\right\}_{2}\right]$}

A solution of $\mathrm{CdCl}_{2}(0.037 \mathrm{~g}, 0.20 \mathrm{mmol})$ was dissolved in methanol $(5 \mathrm{~mL})$, heated for 20 minutes, before being added dropwise to a solution of L1 $(0.051 \mathrm{~g}, 0.10 \mathrm{mmol})$ which was dissolved in methanol $(10 \mathrm{~mL})$. The colourless solution was further heated for 45 minutes before being left to evaporate at room temperature. After three weeks, the solution afforded $\left[\left\{\mathrm{CdCl}_{2}\left(\mathrm{CH}_{3} \mathrm{OH}\right)(\mathrm{L} 1) \mathrm{CdCl}_{2}\right\}_{2}\right]$ as colourless crystals in low yield $(0.015 \mathrm{~g}, 16 \%)$.

\section{$\left[\left(\mathrm{CdBr}_{2}\right)_{2}\left(\mathrm{~L}_{2}\right)\left(\mathrm{CH}_{3} \mathrm{OH}\right)_{2}\right]$}

A solution of $\mathrm{CdBr}_{2}(0.0195 \mathrm{~g}, 0.072 \mathrm{mmol})$ was dissolved in water $(5 \mathrm{~mL})$, heated for 20 minutes, before being added dropwise to a solution of L2 $(0.0180 \mathrm{~g}, 0.036 \mathrm{mmol})$ in methanol-acetonitrile $(15 \mathrm{~mL})$. The colourless solution was heated for 45 minutes and left to evaporate at room temperature. After a week, the solution afforded $\left[\left(\mathrm{CdBr}_{2}\right)_{2}(\mathrm{~L} 2)\left(\mathrm{CH}_{3} \mathrm{OH}\right)_{2}\right]$ as colourless crystals in good yield $(0.012 \mathrm{~g}, 75 \%)$.

\section{Results and Discussion}

Di-2-pyridylmethaneamine (dpma) was synthesized by using reductive amination methods which requires two steps of reactions as described in the literature procedures [14]. In the first step of the method, di-2-pyridyl ketone (i) was treated with hydroxylamine to produce di-2-pyridyl ketone oxime (ii) and reduced by zinc powder in aqueous ammonia to give di-2-pyridylmethaneamine (dpma) in 90\% yield (Scheme 1). 
<smiles>O=C(c1ccccn1)c1ccccn1</smiles>

i i) $\mathrm{NH}_{2} \mathrm{OH} \cdot \mathrm{HCl}$

ii) $\mathrm{H}_{2} \mathrm{O}$

iii) $\mathrm{EtOH}$<smiles>ON=C(c1ccccn1)c1ccccn1</smiles>

ii

i) $\mathrm{Zn}$

ii) $\mathrm{NH}_{3}$ (aqueous)<smiles>NC(c1ccccn1)c1ccccn1</smiles>

dpma, $90 \%$

Scheme 1. Synthesis of dpma from di-2-pyridyl ketone

After the dpma compound was obtained, it was further reacted with isopthalolyl chloride and terephthaloyl chloride in dry dichloromethane to give two new doubly bidentate bridging ligands, namely 1,3- $N$, $N$ '-[bis(di(pyridin-2yl)methyl)]isophthalamide (L1) and 1,4-N,N'-bis[(di(pyridin-2-yl)methyl)]terephthalamide (L2), respectively. The products were subjected for elemental analysis and the results obtained (Table 1) show good agreement between theoretical and experimental data of L1 and L2, as proposed earlier in Figure 1.

Table 1. Elemental analysis data for compounds L1 and L2

\begin{tabular}{lcccccc}
\hline \multirow{2}{*}{ Compounds } & \multicolumn{2}{c}{$\mathbf{C}(\%)$} & \multicolumn{2}{c}{ H(\%) } & \multicolumn{2}{c}{ N(\%) } \\
\cline { 2 - 7 } & Calcd. & Found & Calcd. & Found & Calcd. & Found \\
\hline L1 & 71.98 & 70.13 & 4.83 & 4.98 & 16.79 & 15.63 \\
L2 & 71.98 & 71.83 & 4.83 & 4.08 & 16.79 & 16.05 \\
\hline
\end{tabular}

In the IR spectra of the ligands, strong absorbance bands which were indicated at $1650-1652 \mathrm{~cm}^{-1}$ were assigned to $\mathrm{C}=\mathrm{O}$ stretching of the amide moieties. Strong bands of NH stretches which were observed at range $3211-3217 \mathrm{~cm}^{-}$ ${ }^{1}$ confirmed the formation of amide coupling that generate the respective bridging ligands. In similar to the IR spectra, the ${ }^{1} \mathrm{H}$ NMR of compound L1 and L2 also showed all resonances that were consistent with the expected 2fold symmetric disubstituted compound. The NH peaks were observed at range $8.87-8.96$ ppm, respectively. The difference in chemical shift in either IR and NMR spectra of L1 and L2 was due to the different conformations of the amides about the 1,3 and 1,4-phenyl cores. This different was also reported in our previous study using terephathaloyl and isophthaloyl based moieties [13]. The electrospray mass spectrum showed peaks at $\mathrm{m} / \mathrm{z} 501.1$ and 522.4, which corresponded to $[\mathrm{L} 1+\mathrm{H}]^{+}$and $[\mathrm{L} 1+\mathrm{Na}]^{+}$. Meanwhile, a peak at $\mathrm{m} / \mathrm{z} 501.2$ which corresponding to $[\mathrm{L} 2+\mathrm{H}]^{+}$and $[\mathrm{L} 2+\mathrm{Na}]^{+}$was observed at $\mathrm{m} / \mathrm{z} 523.2$ in a low relative abundance.

In order to determine the molecular structure of the ligands, compounds L1 and L2 were dissolved in hot ethanol and left to evaporate at room temperature. Crystals of L2 were obtained in two weeks and subjected for X-ray crystallography while L1 remain as brown powder. Compound L2 crystallizes in the triclinic space group $P$-1, with one molecule of ligand L2 in the asymmetric unit. The phenyl core is planar, although the amide groups are twisted 
slightly out of the plane of the ring (torsion angles 119.60 and $117.05^{\circ}$ ). The two di-2-pyridyl units are further twisted relative to the phenyl, as shown in Figure 3.

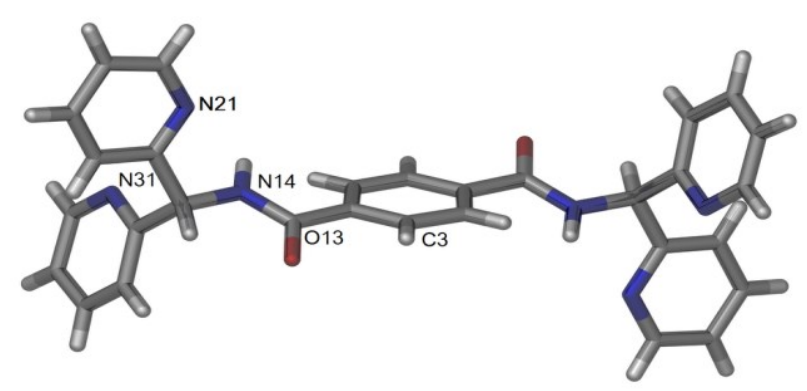

Figure 3. The perspective view of the asymmetric unit of L2

As observed in the crystal structure, the two pyridyl rings are not co-planar. The rings are arranged in trans conformations which brought the nitrogen atoms from the two pyridyl rings closer. This conformation has been observed in a crystal structure of a related chelating ligand, namely 1,2-bis(di-pyridylaminomethyl)benzene [2]. The packing of L2 is stabilized by supramolecular interaction $(\mathrm{C}-\mathrm{H} \cdots \pi)$ between the hydrogen atom from the phenyl ring and the pendant pyridine with H-centroid distance of $2.788 \AA$ (Figure 4). This distance is closed to other edgeon $\mathrm{C}-\mathrm{H} \cdots \pi$ interaction distances reported for other compounds [15].

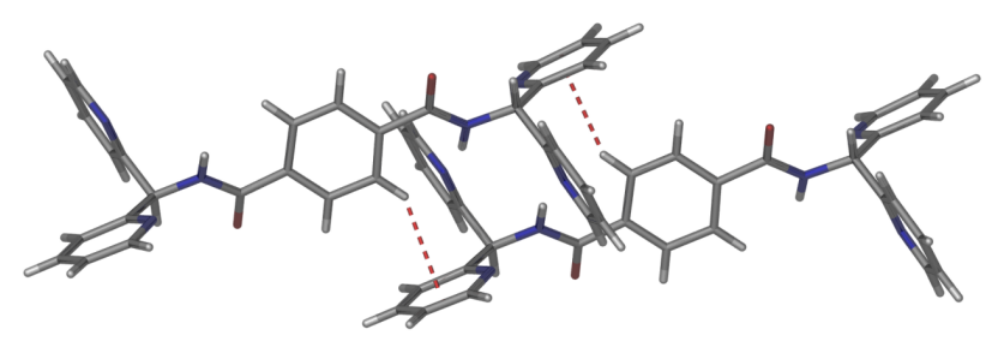

Figure 4. The extended view of compound $\mathrm{L} 2$ with a $\mathrm{C}-\mathrm{H} \cdots \pi$ interaction showing by dashed line

To further understand the types of structures and coordination chemistry of L1 and L2, these ligands were reacted with a range of metal salts to provide variety geometries and coordination numbers for the metal component. Reaction with selected metal salts such as copper, cobalt, palladium and zinc chloride produced only oils or oily solids that were not further characterized or could not be crystallized. Further attempts at these reactions using different ratios (1:1 and 1:2 metal-to-ligand ratios) and different solvent mixtures generally failed to give cleanly isolatable products. Fortunately, reaction of L1 and L2 with cadmium chloride and cadmium bromide gave products in crystals form, highly suitable for X-ray crystallography.

\section{X-ray crystallography of cadmium complexes}

Complex of L1, with formula molecule $\left[\left\{\mathrm{CdCl}_{2}\left(\mathrm{CH}_{3} \mathrm{OH}\right)(\mathrm{L} 1) \mathrm{CdCl}_{2}\right\}_{2}\right]$ crystallizes in the triclinic space group $P-1$, with one molecule of L1, two cadmium atoms, four coordinated chloride anions and one coordinated methanol molecule in the asymmetric unit (Figure 5). The Cd-N bond lengths are in the range 2.318(5) - 2.371(5) $\AA$ which are similar to many previous literature studies [15-20]. This complex has two cadmium atoms with trigonal bipyramidal geometries, although the cadmium atoms have quite different donor sets. $\mathrm{Cd}(1)$ is coordinated by two nitrogen atoms from the pendant pyridyl rings of L1, two chloride atoms (one bridging and one monodentate), while the second cadmium atom $\mathrm{Cd}(2)$ is coordinated by two nitrogen atoms from the pyridyl rings of L1, two chloride atoms and one methanol molecule. In similar manner to related ligands, [17] ligand L1 uses all four nitrogen donors to 
coordinate with the cadmium atoms. The distance between $\mathrm{Cd} 1-\mathrm{Cd} 2$ is $6.40 \AA$, while the distance between the two cadmium atoms bridged by the chloride anions is much shorter at $3.68 \AA$. The coordination mode of L1 in this complex has quite a different motif compared with complexes incorporating other ligands based on a 1,3-phenyl core, such as 1,3-bis(di-2-pyridylaminomethyl)benzene [2]. In previous work, reaction of this ligand with silver nitrate gave discrete [1+1] metallo-macrocycle complex, while reaction with silver perchlorate and silver hexafluorophosphate gave 1-D coordination polymers [17]. The previous study revealed that ligand 1,3-bis(di-2pyridylaminomethyl)benzene acted as a divergent bridging unit, with only two of the four pyridine rings involved in the coordination to form the complexes.

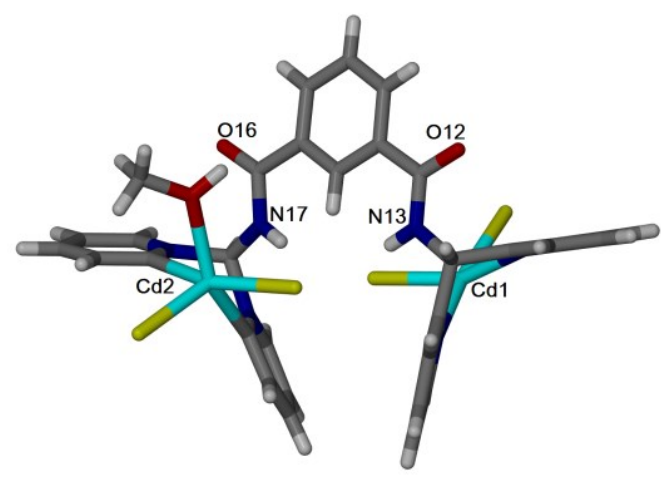

Figure 5. A perspective view of the asymmetric unit of complex $\left[\left\{\mathrm{CdCl}_{2}\left(\mathrm{CH}_{3} \mathrm{OH}\right)(\mathrm{L} 1) \mathrm{CdCl}_{2}\right\}_{2}\right]$

The extended view of complex L1 shows that the bridging chloride atoms connect the two dinuclear units to form a dimer as shown in Figure 6.

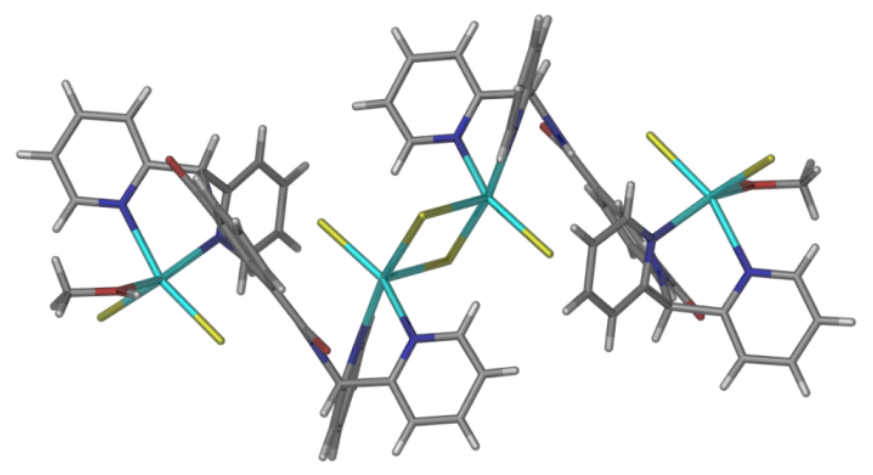

Figure 6. An exended view of complex $\left[\left\{\mathrm{CdCl}_{2}\left(\mathrm{CH}_{3} \mathrm{OH}\right)(\mathrm{L} 1) \mathrm{CdCl}_{2}\right\}_{2}\right]$

Complex with L2 was obtained in 75\% yield by slow evaporation of a methanol-acetonitrile solution containing L2 and cadmium bromide. Single, rectangular, block-shaped crystals of complex L2 were separated from the clump and subjected to single crystal X-ray crystallography. The structure obtained by X-ray crystallography reveals the formation of a dinuclear complex, $\left[\left(\mathrm{CdBr}_{2}\right)_{2}(\mathrm{~L} 2)\left(\mathrm{CH}_{3} \mathrm{OH}\right)_{2}\right]$. In contrasts to the complex above, this complex crystallizes in the monoclinic space group, $P 2_{1} / \mathrm{c}$ with half a molecule of L2, one cadmium atom, two coordinated bromide anions and one coordinated methanol in the asymmetric unit (Figure 7). In this structure, the ligand acts as a tetradentate bridge to link two cadmium atoms and form a discrete dinuclear complex with a 2:1 metal to ligand ratio. The cadmium atom has distorted trigonal bipyramid geometry with one of the chelating pyridyl and one coordinated methanol donor occupying the axial positions. The monodentate pyridine donors twist back towards the core of the ligands in the similar manner to that observed in the dinuclear complexes described earlier. The $\mathrm{Cd}-\mathrm{N}$ 


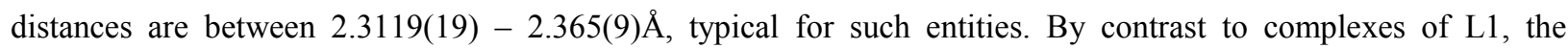
chelating rings in this complex is twisted by ca. $63.3^{\circ}$ from the plane of the central phenyl core, which is approximately three times greater than the torsion angles observed in previous complexes reported by us [17]. Due to the para substitution of the central arene core, complex of L2 have a considerably longer Cd-Cd distance (12.261 $\AA$ ) than those observed in complex of L1. In the crystal structure, it was seen that the discrete complexes were connected to each other by intermolecular hydrogen bonding interactions between the oxygen of the carbonyl group and the coordinated methanol solvent $(d=1.903 \AA)$ to form 1-dimensional hydrogen bond chains (Figure 8$)$. The crystallographic data for the three crystals compounds described in this study is listed in Table 2 for reference.

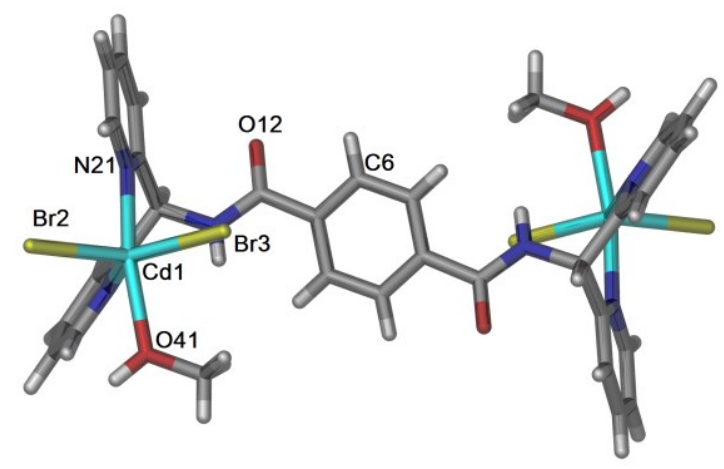

Figure 7. A perspective view of complex $\left[\left(\mathrm{CdBr}_{2}\right)_{2}(\mathrm{~L} 2)\left(\mathrm{CH}_{3} \mathrm{OH}\right)_{2}\right]$

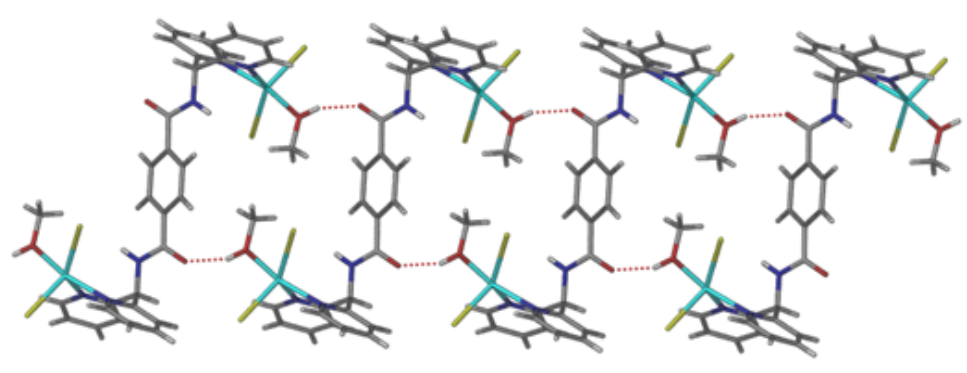

Figure 8. A perspective view of the 1-dimensional hydrogen bonded chains in complex $\left[\left(\mathrm{CdBr}_{2}\right)_{2}(\mathrm{~L} 2)\left(\mathrm{CH}_{3} \mathrm{OH}\right)_{2}\right]$

The crystal structure of compounds L2, and two new complexes have been deposited to Cambridge Crystallograpic Data Centre (CCDC) with reference number 1042070, 1042068 and 1042069, respectively.

Table 2. Crystal data for ligand L2 and complexes of L1 and L2, respectively

\begin{tabular}{llll}
\hline Compounds & $\mathbf{L 2}$ & {$\left[\left\{\mathbf{C d C l}_{\mathbf{2}}\left(\mathbf{C H}_{\mathbf{3}} \mathbf{O H}\right)(\mathbf{L 1}) \mathbf{C d C l}_{2}\right\}_{2}\right]$} & {$\left[\left(\mathbf{C d B r}_{2}\right)_{2}(\mathbf{L} 2)\left(\mathbf{C H}_{3} \mathbf{O H}\right)_{2}\right]$} \\
\hline Empirical Formula & $\mathrm{C}_{30} \mathrm{H}_{24} \mathrm{~N}_{6} \mathrm{O}_{2}$ & $\mathrm{C}_{31} \mathrm{H}_{28} \mathrm{Cd}_{2} \mathrm{Cl}_{4} \mathrm{~N}_{6} \mathrm{O}_{3}$ & $\mathrm{C}_{32} \mathrm{H}_{32} \mathrm{Br}_{4} \mathrm{Cd}_{2} \mathrm{~N}_{6} \mathrm{O}_{4}$ \\
Formula weight & 500.55 & 899.19 & 1109.08 \\
Crystal system & Triclinic & Triclinic & Monoclinic \\
Space group & $P-1$ & $P-1$ & $P 2_{1} / c$ \\
$a(\AA)$ & $8.4621(4)$ & $10.0062(6)$ & $9.4783(2)$ \\
$b(\AA)$ & $8.8809(5)$ & $13.7799(9)$ & $13.8293(3)$ \\
\hline
\end{tabular}


Table 2 (cont'd). Crystal data for ligand L2 and complexes of L1 and L2, respectively

\begin{tabular}{|c|c|c|c|}
\hline Compounds & $\mathbf{L 2}$ & {$\left[\left\{\mathrm{CdCl}_{2}\left(\mathrm{CH}_{3} \mathrm{OH}\right)(\mathrm{L1}) \mathrm{CdCl}_{2}\right\}_{2}\right]$} & {$\left[\left(\mathrm{CdBr}_{2}\right)_{2}(\mathrm{~L} 2)\left(\mathrm{CH}_{3} \mathrm{OH}\right)_{2}\right]$} \\
\hline$c(\AA)$ & $9.7782(5)$ & $13.9357(8)$ & $14.3145(3)$ \\
\hline$\alpha\left(\left(^{\circ}\right)\right.$ & $68.479(5)$ & $64.558(6)$ & 90 \\
\hline$\beta\left({ }^{\circ}\right)$ & $72.112(5)$ & $81.854(5)$ & $107.028(3)$ \\
\hline$\gamma\left({ }^{\circ}\right)$ & $69.326(5)$ & $82.060(5)$ & 90 \\
\hline Volume $\left({ }^{3}\right)$ & $626.13(6)$ & $1711.23(18)$ & $1794.06(7)$ \\
\hline$Z$ & 1 & 2 & 2 \\
\hline $\begin{array}{l}\text { Density } \\
\text { calculated }\left(\mathrm{Mg} / \mathrm{m}^{3}\right)\end{array}$ & 1.328 & 1.745 & 2.053 \\
\hline $\begin{array}{l}\text { Absorption } \\
\text { coeficient }\left(\mathrm{mm}^{-1}\right)\end{array}$ & 0.087 & 1.597 & 1.685 \\
\hline $\mathrm{F}(000)$ & 262 & 888 & 1068 \\
\hline Crystal size $\left(\mathrm{mm}^{3}\right)$ & $0.41 \times 0.26 \times 0.09$ & $0.12 \times 0.14 \times 0.06$ & $0.43 \times 0.04 \times 0.03$ \\
\hline $\begin{array}{l}\text { Theta range } \\
\text { for data }\left({ }^{\circ}\right)\end{array}$ & $2.29-29.63$ & $2.48-29.81$ & $2.69-29.92$ \\
\hline Reflections collected & 12303 & 8293 & 4736 \\
\hline $\begin{array}{l}\text { Observed reflections } \\
{[\mathrm{I}>2 \mathrm{~s}(\mathrm{I})]}\end{array}$ & 6245 & 5989 & 3676 \\
\hline $\begin{array}{l}\text { Data/restraints/ } \\
\text { parameters }\end{array}$ & $6245 / 3 / 343$ & $8293 / 0 / 416$ & $4736 / 0 / 218$ \\
\hline Goodness-of-fit on $\mathrm{F}^{2}$ & 0.902 & 1.074 & 0.932 \\
\hline $\mathrm{R}_{1}[\mathrm{I}>2 \mathrm{~s}(\mathrm{I})$ & 0.0341 & 0.0630 & 0.0226 \\
\hline$w R_{2}$ (all data) & 0.0780 & 0.1851 & 0.0479 \\
\hline $\begin{array}{l}\text { Largest diff. } \\
\text { peak and hole }\left(\mathrm{e} . \AA^{-3}\right)\end{array}$ & 0.233 and -0.198 & 3.664 and -2.101 & 0.569 and -0.594 \\
\hline
\end{tabular}

\section{Conclusion}

The synthesis and coordination chemistry of doubly bidentate bridging ligands with dpma units have been successfully explored. It was confirmed from this study that ligands L1 and L2 used all four nitrogen donor atoms from dpma chelating units to bind with the cadmium ions, and forming stable multinuclear complexes. Like other ligands incorporating two di-2-pyridylmethyl chelating motifs, ligands L1 and L2 readily bridge two metals with bidentate chelation at each metal centre. The work described in this paper could be further expanded by finding conditions to limit hydrolysis of the ligands upon reaction with other metal salts, as from this study, only cadmium complexes can be isolated.

\section{Acknowledgments}

The authors greatly acknowledge scientific and financial supports from Universiti Malaysia Terengganu, Ministry of Higher Education Malaysia and the University of Adelaide.

\section{References}

1. Sumby C. J. (2011). Bridging ligands comprising two or more di-2-pyridylmethyl or amine arms: alternatives to 2,2'- bipyridyl-containing bridging ligands. Coordination Chemistry Review, 255: 1937 - 1967. 
2. Antonioli B., Clegg J. K., Bray D. J., Gloe K., Gloe K., Kataeva O. N., Lindoy L. F., McMurtrie J. C., Steel P. J., Sumby C. J. and Wenzela M. (2006). Silver(I) complexation of linked 2,2'-dipyridylamine derivatives. Synthetic, solvent extraction, membrane transport and X-ray structural studies. Dalton Transaction, 40: 4783 4794.

3. Sumby C. J. and Steel P. J. (2007). Steel Mono- and dinuclear ruthenium complexes of bridging ligands incorporating two di-2-pyridylamine motifs: Synthesis, spectroscopy and electrochemistry. Polyhedron, 26: $5370-5381$.

4. Antonioli B., Bray D. J., Clegg J. K., Gloe K., Gloe K., Jager A., Jolliffe K. A., Kataeva O. N, Lindoy L. F., Steel P. J., Sumby C. J. and Wenzel M. (2008). Interaction of copper(II) and palladium(II) with linked 2,2dipyridylamine derivatives: Synthetic and structural studies. Polyhedron, 27: 2889 - 2898.

5. Sumby C. J. and Steel P. J. (2007). Coordination chemistry of di-2-pyridylamine-based bridging heterocyclic ligands: A structural study of coordination polymers and discrete dinuclear complexes. Inorganic Chimica Acta, 360: 2100 - 2114.

6. Philip, V., Suni, V., Kurup., P. R. M. and Nethai, M. (2005). Novel binuclear copper(II) complexes of di-2pyridine ketone $N(4)$-methyl, N(4)-phenylthiosemicarbazone: Structural and spectral investigation, Polyhedron, 24: $1133-1142$.

7. Suni, V., Kurup, P. R. M. and Nethaji, M. (2007). Structural and spectral investigation on some new Ni(II) complexes of-di-2-pyridyl ketone N(4)-phenylthiosemicarbazone. Polyhedron, 26: $3097-3102$

8. Wu, S. H., Zhong, Y. W. and Yao J. (2013). 2,3-di(2-pyridyl)-5-phenylpyrazine: ANN-CNN-type bridging ligand for dinuclear transition-metal complexes. Chemistry Asian Journal, 8: $1504-1513$

9. Zhong, Y. W, Wu, S. H., Burkhardt, S. E. and Abruna H. D. (2011). Mononuclear and dinuclear ruthenium complexes of 2,3-di-2-pyridyl-5,6-diphenylpyrazine: Synthesis and spectroscopic and electrochemical studies. Inorganic Chemistry, 50: $517-524$.

10. Trilla, M., Pleixats, R., Man, M. W. C., Bied, C. and Moreau, J. J. E. (2006). Hybrid organic-inorganic silica materials containing di(2-pyridyl)methylamine-palladium dichloride complex as recyclable catalysts for Suzuki cross-coupling reactions. Tetrahedron, 47: $2399-2403$.

11. Chang, J., Plummer, S., Berman, E. S. F., Striplin, D. and Blauch, D. (2004). Synthesis and characterization of bis(di-2-pyridylmethanamine)ruthenium(II). Inorganic Chemistry, 43: 1735 - 1742.

12. Kadir, M. A, Ramli, R., Kassim, N., Mansor, N., Sumby, C. J. (2015). Synthesis, structural and spectroscopic studies of palladium(II) metallo-macrocyles containing ancillary blocking ligands and $N, N^{\prime}-2,6$-bis(3pyridylmethyl)pyridine dicarboxamide. Malaysian Journal of Analytical Sciences, 19(3): 520 - 530.

13. Idris, N. S. B., Kadir, M. A. and Khandaker, M. M. (2017), Synthesis, characterization and coordination chemistry of $N, N^{\prime}$-bis(3-pyridylmethyl)benzene-1,4-dicarboxamide with palladium and ruthenium salts. Asian Journal of Chemistry, 29(7): 1459 - 1462.

14. Renz, M., Hemmert, C. and Meunier, B. (1998). Synthesis of bis(di-2-pyridylmethyl)amine (BDPMA) by a novel one-pot multi-step reductive amination with molecular sieves and $\mathrm{Zn} / \mathrm{i}-\mathrm{PrOH}$. European Journal of Inorganic Chemistry, 30: $1271-1273$.

15. Kitagawa, S., Kitaura, R. and Noro, S. I. (2004). Functional porous coordination polymers. Angewante Chemistry International Edition, 43: 2334 - 2375.

16. Liu, T. F., Lu, J. and Cao R. (2010). Coordination polymers based on flexible ditopic carboxylate or nitrogendonor ligands. Crystal Engineering Communication, 12: 660 - 670.

17. Abdul-Kadir, M., Clements, P. R., Hanton, L. R., Hollis, C. A. and Sumby C. J. (2012). Pre-organisation or a hydrogen bonding mismatch: Silver(I) diamide ligand coordination polymers versus discrete metallomacrocyclic assemblies. Supramolecular Chemistry, 24: $627-640$.

18. Abdul-Kadir, M., Hanton, L. R. and Sumby, C. J. (2011). Self-assembled metallo-macrocycle based coordination polymers with unsymmetrical amide ligands. Dalton Transaction, 40: $12374-12380$.

19. Abdul-Kadir, M., Hanton, L. R. and Sumby, C. J. (2012). Building blocks for coordination polymers: selfassembled cleft like and planar discrete metallo macrocyclic complexes. Dalton Transaction, 41: $4497-4505$.

20. Kadir, M. A., Mansor, N., Yusof, M. S. M. and Sumby, C. J. (2014). Synthesis and crystal structure of N-6-[(4pyridylamino) carbonyl]-pyridine-2-carboxylic acid methyl ester zinc complex. Complex Metals, 1: 32 - 37 . 